\title{
CHAPTER X
}

\section{HUMAN RIGHTS CONDITIONALITY IN THE EU'S NEWLY CONCLUDED ASSOCIATION AGREEMENTS WITH THE EASTERN PARTNERS}

\author{
Szilárd Gáspár-Szilágyi*
}

\section{INTRODUCTION}

On 27 June 2014 the EU has signed association agreements (AAs) with three of its Eastern Partners: Ukraine, Moldova and Georgia. The AAs are meant to replace the existing Partnership and Cooperation Agreements (PCAs) that governed the bilateral relationships between the EU and the three Eastern Partners. Their main purpose is to deepen the political and economic ties between the contracting parties and to gradually integrate these countries into the legal and economic system of the EU (Kawecka-Wyrzykowska, 2015, p. 79). This is to be done by establishing "an enhanced institutional framework and innovative provisions on regulatory and legislative approximation" (Van der Loo et al., 2014, p.1).

All three agreements are underpinned by two different forms of conditionality. First, the preambles and initial articles of the AAs include several provisions related to the Eastern Partners' commitments to the 'common values' of the EU, such as the respect for human rights, democracy and the rule of law. Some of these are contained in so called 'essential elements' clauses. Second, the parts dealing with the DCFTA include 'market access' conditionality on the basis of which additional access of the Eastern Partners' to the EU Internal Market depends on whether they have successfully implemented their legislative approximation commitments.

This Chapter aims to provide a critical discussion of the first type of conditionality, more specifically human rights conditionality under the three AAs. The underlying purpose is to see whether the 'human rights' conditionality clauses included in these agreements are a simple matter of 'legal inflation', mere political commitments, or whether the EU has

\footnotetext{
* Szilárd Gáspár-Szilágyi, PhD, LLM is currently a postdoctoral research fellow at University of Amsterdam,
} Asmterdam Centre for European Law and Governance (ACELG) funded by ACCESS Europe. 
managed to design legally enforceable provisions and has provided a common ground to be followed in this field.

In light of the above, Section II of this Chapter provides a succinct overview of the evolution of human rights conditionality in EU external relations and the evolution of the Eastern Partnership. This section also introduces the types of human rights clauses that are included in the three AAs, mainly the 'essential elements' clause and its counterpart the 'non-execution' clause. Section III then critically assesses the coverage of the essential elements clauses, with a specific focus on the conduct that is required from the contracting parties, the 'common values' which are included in such clauses and the human rights instruments they refer to. Section IV is reserved for the institutional framework under the AAs and the operation of the 'non-execution' clauses in case an 'essential element' of the agreements is breached. Section V discusses whether these clauses have managed to tackle some of the existing challenges of human rights conditionality, with a specific focus on monitoring and implementing mechanisms. Section VI is meant for conclusions.

\section{SOME BACKGROUND INFORMATION}

\section{Human Rights Conditionality in EU International Agreements}

In the 1980s and 1990s US and EU officials began including human rights conditionality in their preferential trade (PTA) and free trade agreements (FTA) with other trading partners (Aaronson, 2011, p. 429). The first human rights clauses were included in agreements concluded by the EU in the early 1990s with South American and Central and Eastern European States (CEES), while the current policy framework for including human rights clauses dates from 1995 (European Parliament, 2014, pp. 6-7; Bartels, 2014, pp. 12-13). These provisions go beyond what is required by the General Agreement on Tariffs and Trade (GATT), and by the WTO framework. Legal academia refers to them as WTO-extra provisions and besides human rights they can contain clauses on environmental protection, labour standards, data protection, consumer protection, etc. (Horn et al., 2010).

Human rights conditionality is to be found in different EU international agreements with very different objectives. It appears in PTAs and FTAs meant to create closer economic cooperation between the contracting parties or a free trade area; it appears in cooperation agreements with the purpose of creating closer economic and political ties, association agreements with an enlargement purpose, or the current association agreements which do not set out EU accession among their objectives. Furthermore, human rights conditionality often materializes in the form of 'human rights' clauses found in various parts of the agreements or in the form of references to human rights and other values in the preamble of the agreements. 
One such human rights clause is the 'essential elements' clause, according to which human rights form an essential element of the agreement (Aaronson, 2011, p. 439). The first 'essential elements' clause was included in the EC-Argentina Cooperation Agreement in 1990 (Hachez, 2015, p. 8). Depending on the agreement, the 'essential elements' clause can refer in a generic manner to 'human rights' or it can refer to specific international and regional human rights instruments. In some cases, such as in the EU-Korea Framework Agreement, this clause also refers to "other relevant international human rights instruments" (Article 1(1)), allowing thus the inclusion of future human rights agreements (European Parliament, 2014, p. 9). Such clauses are coupled with 'non-execution' clauses found towards the end of the agreements, under which the contracting parties agree that either party may suspend the agreement if one of these 'essential elements' is violated by the other (Leino, 2005, p. 333). Historically, 'non-execution' clauses have taken up two different forms. The so called 'Baltic' clauses lacked flexibility since a party could immediately suspend the application of the agreement if there was a serious breach of an essential element of the agreement. On the other hand, the 'Bulgarian' clause is more flexible and became the standard clause since it allows either party to take 'appropriate measures' in case of a breach by the other party, following initial consultations (Hachez, 2015, p. 10).

However, the usefulness of human rights clauses has been questioned by legal academics and economists. Some view it as 'legal inflation' and doubt whether some of these clauses enjoy legal enforceability (Horn et al., 2010, pp. 1579-1580). In practice the human rights clauses have been treated rather as political clauses, with occasional human rights elements (European Parliament, 2014, p. 12), providing leverage to the EU in case of any future grave human rights violations committed by the contracting partner. Others view such clauses as beneficial, as they set up mechanisms for dialogue. Furthermore, they allow civil society to monitor human rights compliance, and they make human rights part of the trade relationship (Bartels, 2005). However, as it will be discussed in Section V, the role of civil society in the enforcement of EU human rights clauses is fairly minimal compared to their US counterparts.

Another criticism has to do with what some authors view as a patronizing attitude of the EU towards developing states and former colonies, requiring them to follow Euro-centric human rights, while the EU mostly fails to include such clauses in agreements concluded with stronger, more developed contracting parties (Leino, 2005). For e.g. the FTAs with Australia and New Zealand failed because of the EU's push for human rights conditionality. Even so, the recent agreement with South Korea is a good example that such clauses can be included in agreements with stronger or more developed states as well. 


\section{The New Association Agreements with the Eastern Partners}

After the fall of Communism the EU began negotiating international agreements with members of the former 'Eastern Block'. The 'Europe Agreements' concluded with CEECs (for e.g. Hungary, Poland, Romania, Czech Republic, etc.) eventually lead to the EU accessions of 2004 and 2007, while Croatia (2013) was under a different policy area designed for the Western Balkans. Even though prior to Lisbon the European Community did not have internal and external competences in areas such as human rights, democratic principles and the rule of law, the Europe Agreements contained two types of conditionality. The first type of conditionality was related to the EU acquis in its strict sense, while the second type of conditionality related to the political Copenhagen criteria (Kochenov, 2014, p. 57). With other Eastern European states, the former Community concluded partnership and cooperation agreements (PCAs) in the 1990s, which provided a channel through which EU values could be exported (Matta, 2014; Kochenov, 2014). Until the establishment of the European Neighbourhood Policy in 2004 the export of EU norms and values was rather "unspecific in substance and lacked an articulated underlying strategy" (Hillion, 2014, p. 13).

Following the Lisbon amendments, the EU under Article 8 TEU is under an obligation to develop "a special relationship with neighbouring countries". This article lays down the foundation of the export of EU norms and values into the European Neighbourhood (Hillion, 2014, p. 15). In 2009 the Eastern Partnership (EaP) was launched in Prague, with the aim of bringing the Eastern Partners (Ukraine, Georgia, Moldova, Armenia, Azerbaijan and Belarus) closer to the EU. According to the European External Action Service (EEAS), the EaP "is based on a commitment to the principles of international law and fundamental values, including democracy, rule of law and respect for human rights and fundamental freedoms, as well as to a market economy, sustainable development and good governance" (EEAS, 2015). Furthermore, the EaP offers an upgrade of relations with three major dimensions: (a) Association Agreements, (b) Agreements on DCFTA and (c) Visa Facilitation and Readmission agreements (Movchan and Shportyuk, 2012, p. 5).

In the last two years the EU managed to conclude under Article 217 TFEU the AAs with Ukraine, Moldova and Georgia. These agreements were concluded as 'mixedagreements' and will enter into force when all parties to the agreements (the EU, the 28 Member States and the Eastern Partners) have ratified them, while some parts falling under exclusive EU competence are provisionally applicable. All three agreements go beyond the previous PCAs, with the aim of setting up a Deep and Comprehensive Free Trade Area (DCFTA) with the Eastern Partners. Besides provisions on trade, the new AAs include numerous clauses on human rights, arms control, investment protection, data protection, etc. In many ways the new AAs are similar to the afore-mentioned 'Europe Agreements'. Still, there is no automatic link between association and accession to the EU and the AAs carefully 
avoid any direct reference to the associate countries' future EU membership (Van der Loo et al., 2014, p.10).

The relationship with Armenia, Azerbaijan and Belarus are different (Ghazaryan and Hakobyan, 2014; Karliuk 2014). Armenia has decided in 2013 not to initial the negotiated AA with the EU, which included a DCFTA, but instead joined the Eurasian Economic Union with Russia, Belarus and Kazakhstan (EEAS Armenia, 2015). Azerbaijan started negotiations of an AA with the EU in 2010, but due to the country's growth stimulated by its oil reserves, the future of this agreement is uncertain (EEAS Azerbaijan, 2015). The relations with Belarus are less advanced due to the political situation in that country (EEAS Belarus, 2015). Russia on the other hand is not included in the EaP (Kalinichenko, 2014). The relationship with Russia is still governed by the 1997 PCA and due to the Ukrainian crisis the relationship between the two has deteriorated (DG Trade Russia, 2015).

Before providing an in-depth analysis of the human rights clauses in Sections III and IV, a short overview is needed of the types of clauses that can be found in the three AAs.

\begin{tabular}{|l|c|c|c|c|}
\hline Association & 'Commo & $\begin{array}{c}\text { 'Essential } \\
\text { Elements' } \\
\text { Clause }\end{array}$ & $\begin{array}{c}\text { General } \\
\text { Dispute } \\
\text { Settlement }\end{array}$ & $\begin{array}{c}\text { 'Non-execution' } \\
\text { Clause }\end{array}$ \\
\hline EU-Georgia & Preamble & Art. 2(1) & Art. 421 & Art. 422 \\
\hline EU-Moldova & Preamble & Art. 2(1) & Art.454 & Art. 455 \\
\hline EU-Ukraine & Preamble & Aer. 2(1) & Art. 477 & Art. 478 \\
\hline
\end{tabular}

Figure 1: Human Rights and Dispute Settlement Clauses in the new AAs

Based on the above table, all three AAs 'recognise' in their preambles that the 'common values' on which the EU is built "lie also at the heart of political association and economic integration" envisaged by the agreements. These common values include democracy, respect for human rights and fundamental freedoms, and the rule of law. The three AAs, in various forms throughout their preambles, also include as 'common values' good governance, respect for the rights of national minorities, non-discrimination of people belonging to minorities, respect for diversity, human dignity and even commitment to the principles of free market economy.

Within the body of the agreements, all three AAs include a fairly extensive 'essential elements' clause (infra Section III). However, in addition to the standard references to human rights in the essential elements clauses, human rights (together with other 'common values') reappear in other articles as well (Van der Loo et al., 2014, p.12), such as the ones on political dialogue' (Art. 3(2)h, EU-Georgia AA; Art. 3(2)e, EU-Moldova AA; Art. 4(2)e, EU-Ukraine AA), domestic reforms (Art. 4, EU-Georgia AA; Art. 4(b), EU-Moldova AA; Art. 6, EU-Ukraine AA), the fight against terrorism (Arts. 12 and 20, EU-Georgia AA; Arts. 
11 and 19, EU-Moldova AA; Arts. 13 and 23, EU-Ukraine AA), or Titles III on 'Freedom, Security and Justice'.

The essential elements clauses are coupled with 'Bulgarian' type 'non-execution' clauses to be found towards the end of the agreements (infra Section IV). These clauses, which provide for 'appropriate measures' in case of breaches against the essential elements of the agreement, are preceded by the agreements' general dispute settlement clauses. It must be mentioned that all three AAs include separate dispute settlement clauses for trade and trade-related matters. For e.g., the EU-Georgia AA includes 'trade and trade-related' matters in Title-IV and the specific dispute settlement provisions for these matters are included in Chapter 14 of that Title. Besides these, all three agreements include multiple provisions on the environment and labour rights.

\section{WHAT IS COVERED BY THE 'ESSENTIAL ELEMENTS' CLAUSES?}

According to Bartels, the EU was faced in the 1970s and 1980s with a set of human rights violations committed by some of its trading partners, to which the EU could not respond by suspending the trade agreements under the rebus sic stantibus doctrine (fundamental change of circumstances), found in Article 61(1), VCLT 1969. Therefore, the initial rationale behind the inclusion of an 'essential elements' clause was to create a set of circumstances that in case of change would enable the EU to invoke the rebus sic stantibus rule (Bartels, 2014, p. 12). This initial rationale was most probably changed by the Commission, making this clause effective under a different rule of treaty law, "according to which a party can be considered to have repudiated a treaty by acting in a manner contrary to an assumption on which it is based" (Bartels, 2014, p.12; Art. 60(3)a VCLT 1969).

However, even with the existence of these various rationales, prior to the Lisbon Treaty it was not entirely evident on what legal basis could the EU promote human rights under its external agreements (Leino, 2005, p. 336). After Lisbon, the EU's external human rights agenda has a solid footing in the TEU. Under Article 2 TEU the Union is "founded on the values of respect for human dignity, freedom, democracy, equality, the rule of law and respect for human rights, including the rights of persons belonging to minorities". As mentioned in Section II, these values also appear in the preambles of the newly concluded AAs with the Eastern Partners as 'common values' to the contracting parties. This general 'foundation' clause is further elaborated in Article 3(5) TEU, under which the EU now has a clear mandate to uphold and promote the protection of human rights in "its relations with the wider world". This obligation is further refined in Article 21 TEU on the "General Provisions on the Union's External Action'. Under Article 21(2)b TEU the Union "shall define and pursue common policies and action" in all fields of international relations in order to "consolidate and support democracy, the rule of law [and] human rights". 
In light of the above, there is no doubt that the inclusion of human rights conditionality in the three AAs is now mandated by EU primary law. Moreover, in Section II it has been discussed that human rights do not only permeate the preambles of the newly concluded AAs and their 'essential elements' clauses, but they also appear in various other articles. For the purposes of this Section, the human rights references in the essential elements clauses are relevant. The essential elements clauses in the AAs with Moldova and Georgia are worded identically. According to their Article 2(1):

"Respect for the democratic principles, human rights and fundamental freedoms, as proclaimed in the United Nations Universal Declaration of Human Rights of 1948 and as defined in the European Convention for the Protection of Human Rights and Fundamental Freedoms of 1950, the Helsinki Final Act of 1975 of the Conference on Security and Cooperation in Europe and the Charter of Paris for a New Europe of 1990 shall form the basis of the domestic and external policies of the Parties and constitutes an essential element of this Agreement. Countering the proliferation of weapons of mass destruction, related materials and their means of delivery also constitute essential elements of this Agreement." [highlights added by author]

The essential elements clause in the EU-Ukraine AA is similar and refers to the same international and regional human rights instruments. However, it differs in two aspects. First, similarly to the EU-Korea Framework Agreement, the clause refers to "other relevant human rights instruments" as well, thus, leaving an open ended possibility for future inclusion of international human rights instruments. Second, the last sentence also refers to the respect "for the principles of sovereignty and territorial integrity" and "inviolability of borders and independence".

Let us now turn to a thorough analysis of the essential elements clauses by answering three questions: Which common values are covered? Which types of conduct of the contracting parties are covered? Which instruments and human rights are covered?

\section{Which Common Values?}

Section II.2 provided an overview of the 'common values' to which the contracting parties are committed to, such as the respect of human rights, the rule of law, democracy and good governance. In various forms other common values appeared as well, such as non-discrimination of minorities and the commitment to the principles of a free market economy. According to the Commission, some of these values are also reflected in the 1993 Copenhagen criteria for acceding EU Member States, under which the following have to be ensured: the stability of institutions guaranteeing democracy, rule of law, human rights, and the respect for and protection of minorities (Commission Communication, 2001, p. 5).

In all three essential elements clauses the respect for democratic principles, and human rights and fundamental freedoms appear. This means that a serious breach of human and 
fundamental rights, and democratic principles by one party could lead the other party to adopt 'appropriate measures'. However, several observations are necessary.

First, the commitment to the principles of a free market economy as well as other 'common values', such as the protection of national minorities, the rule of law and good governance are not explicitly included in the essential elements clause. As some authors have noted in the context of the EU-Ukraine AA, this means that the agreements differentiate between 'hard core' common values related to fundamental rights and democratic principles, which can trigger suspension, and a set of other common principles which cannot trigger suspension of the entire agreement (Van der Loo et al., 2014, pp. 12-13), such as the commitment to the principles of a free market economy.

Second, all three agreements include extra essential elements, which go beyond classical human rights and have a strong security aspect to them (Van der Loo et al., 2014, pp. 12-13). The AAs with Moldova and Georgia refer to "countering the proliferation of weapons of mass destruction, related materials and their means of delivery" as an essential element. As previously mentioned, the EU-Ukraine AA also adds the respect to the principles of sovereignty, territorial integrity and inviolability of borders as essential elements. This means that the breach of any of these essential security elements can also trigger the suspension of the agreement.

Third, the AAs do not state what is meant by 'democratic principles' and there might be some reasons for doing so. It is debatable whether these common values represent quantifiable and measurable legal commitments or whether in fact they are rather political clauses. According to Petersmann (2015), the TFEU refers to 'democratic principles' "in terms of multilevel constitutional, parliamentary, deliberative, and participatory democracy that complement the diverse national democratic clauses" (pp. 594-595). Unlike UN law, EU law and the human rights clauses in external EU agreements aim to enforce human rights conditionality (Petersmann, 2015, p. 595). Still, it seems that in practice the Council rather treats these clauses as political clauses with occasional human rights elements (European Parliament, 2014, p. 12). Furthermore, this idea seems to be shared by the Commission as well, according to which the "EU's insistence on including essential elements clauses is not intended to signify a negative or punitive approach", but it is rather meant to promote dialogue and positive measures with the partner country (Commission Communication, 2001, p. 9). This of course means that in practice it will be quite difficult to ascertain when the partner country has seriously breached democratic principles. It also begs the question, whether one of the other 'common values', the rule of law, forms a part of democratic principles and thus forms part of the essential elements of the agreements. 


\section{What Type of Conduct?}

In all three essential elements clauses the respect for human rights shall form the basis of the domestic and external policies of the contracting parties. There are two aspects of this statement that warrant further observation: (a) the type of obligations which the contracting parties have under these clauses, and (b) the territorial coverage of these human rights obligations.

With regard to the first aspect, obligations in general can be classified into positive and negative ones. Under a positive obligation a party has to engage in a certain conduct, while under a negative obligation it has to refrain from engaging in a certain conduct. Traditional human rights law refines these obligations and identifies three of them: the obligation to respect, the obligation to protect and the obligation to fulfil human rights (Bartels, 2005, p. 146). The obligation to 'respect' is a minimum type of obligation for the contracting parties to refrain from committing human rights violations. Unlike the first type of obligation, the obligation to 'protect' requires states/regional entities to ensure that other actors (mainly private ones) do not prevent the enjoyment of rights by other persons. The obligation to 'fulfil' implies the facilitation, promotion and provision of human rights (Bartels, 2014, p. 17). On an initial reading the three essential elements clauses seem to only refer to the obligation to respect human rights. However, based on ECtHR case-law (Von Hannover $v$ Germany [2005] 40 EHRR 1, para 57, citing $X$ and $Y V$ Netherlands [1986] 8 EHRR 235, Stjerna v Finland [1997] 24 EHRR 195) Bartels (2005) has argued that the obligation to 'respect' human rights itself implies positive obligations and not just the obligation to refrain from breaching human rights. Therefore, it is "strongly arguable that the essential elements clause imposes positive obligations on the parties to ensure that human rights and democratic principles are respected, at least in certain cases, even though it merely uses the word 'respect'" (Bartels, 2005, p. 148). Furthermore, some authors have noted that in certain instances contracting parties should be allowed to suspend their obligations under AAs and trade agreements, if the execution of the agreements could jeopardize the attainment of domestic human, labour and social rights objectives (Bartels, 2014, p. 14; infra Section IV).

Regarding the territorial aspect, the essential elements clauses in all three AAs require the respect of human rights by the contracting parties both in their domestic and external policies. This means that the 'non-execution clause' can be triggered by serious breaches of human rights that occurred either domestically or during one of the parties' conduct of its external relations. However, some observations are warranted.

First, since all three AAs have been concluded as 'mixed-agreements', these obligations apply not only to the EU and the three Eastern Partners, but also to the Member States. Therefore, even though an unlikely event, the serious and probably systematic disregard of human rights by one EU Member State could prompt the other party to adopt appropriate 
measures, such as the suspension of meetings and technical co-operation programs. (infra, Section IV).

Second, it has been previously discussed that according to Articles 3(5) and 21 TEU the EU shall be guided by the principle to protect human rights and fundamental freedoms and shall consolidate and support democratic principles and the protection of human rights in its external affairs. Therefore, these essential elements clauses are examples from specific agreements concluded by the EU in its external policy fields in which the afore-mentioned primary EU law obligations are not only restated in the agreements, but 'exported' in order to create the same obligations for the three Eastern Partners.

Third, with regard to the domestic application of the obligation to respect human rights and democratic principles, one must recognise that all three Eastern Partners have territories over which they de facto do not exercise control. For e.g., Moldova does not exercise de facto control over the breakaway Republic of Transnistria, Georgia has similar problems over the breakaway regions of South Ossetia and Abkhazia, while in 2014 Russia had annexed Crimea and the Donbas region is not under the Ukrainian government's control. However, the preambles of the AAs with Moldova and Georgia recognise the importance of the commitment of the three Eastern Partners to settle the conflicts in the breakaway areas. Moreover, these two AAs recognise that the Titles on Trade and Trade-related Matters shall only apply to the breakaway territories once their governments exercise effective control over them (Art. 429(2), EU-Georgia AA; Article 462(2), EU-Moldova AA). The text of the EU-Ukraine AA was initialled before the Crimea and Donbas conflict (Van der Loo et al., 2014, p. 22); therefore, it does not contain similar territorial clauses as the ones found in the AAs with Moldova and Georgia. However, the EU-Ukraine Association Council set out to develop a mechanism through, which the rules of origin provisions of the EU-Ukraine AA can be applied to the occupied territory of Crimea (EU-Ukraine Association Council, 2015).

\section{Which Instruments and Which Rights?}

Whereas some EU trade agreements do not refer to any specific international human rights instruments, most will have a reference at least to the human rights proclaimed in the Universal Declaration of Human Rights (Hachez, 2015, p. 16). Depending on the region in which the partner country originates from, other relevant regional human rights instruments can be included as well. This is the case with the newly concluded AAs with the Eastern Partners. All three of them refer to the respect of human rights proclaimed and defined in the following four instruments: the UDHR, the ECHR, the Helsinki Final Act of 1975 and the Charter of Paris for a New Europe of 1990. In addition to this, as mentioned, the essential elements clause of the EU-Ukraine AA also refers to "other relevant human rights 
instruments". This non-exhaustive clause allows other relevant instruments to be referred to as well, such as the two international covenants, the ICCPR and the ICESCR.

As Aaronson (2011) notes, the UDHR is universal in nature and it applies to everyone whether or not individual governments have formally accepted its principles or not. However, it is a declaration and not a binding legal document. Moreover, not all of the 38 human rights set forth in the UDHR are relevant to trade; furthermore, it does not include certain human rights, which are found in national constitutions (p. 431). For e.g. Article 34 of the Constitution of Moldova refers to the right of access to information as a fundamental right, while Article 37 refers to the right to a healthy environment.

The second instrument, the ECHR is a regional human rights agreement and under the pacta sunt servanda principle it is binding upon the contracting parties (Art. 26, VCLT 1969). Moreover, the parties to the ECHR undertake "to abide by the final judgment" of the European Court of Human Rights (Art. 46, ECHR). All three Eastern Partners have ratified the ECHR; Moldova and Ukraine in 1997 and Georgia in 1999. In 2014 the ECtHR delivered 25 judgments against Moldova and in 21 cases found at least one violation of the Convention. Some of the prominent violations have been committed against the right to free elections, the prohibition of inhuman and degrading treatment, freedom of expression and the right to education (ECtHR Report, Moldova, 2015). In 2014 only 3 judgments were delivered against Georgia and one of them found a violation of several rights, such as the prohibition of collective expulsion of aliens, the right to liberty and security, the right to judicial review, etc. (ECtHR Report, Georgia, 2015). In the case of Ukraine, on the other hand, the Court dealt with 13.804 applications in 2014, most of which were declared inadmissible. The Court delivered 40 judgments, 39 of which found violations of some of the most important rights under the Convention, such as the right to a fair hearing, prohibition of torture, the right to life, etc. (ECtHR Report, Ukraine, 2015). Ukraine's fairly poor human rights record might explain why the drafters found it necessary to include the phrase "other relevant human rights instruments" in the essential elements clause. In Section V it shall be discussed how this fairly poor human rights record lead to a significant amount of human rights and rule of law based reporting and monitoring in Ukraine, on a national, European, regional and international level.

It is also worth reiterating that the essential elements clause binds all parties to the agreement, not just the Eastern Partners. Even though its purpose is to export EU human rights values to the EU's contracting partners, the clause is binding on the 28 Member States and the EU as well. As is known, all 28 EU Member States have ratified the ECHR, but some of them also have significant amount of cases before the ECtHR. One such example is Romania against which the ECtHR delivered 87 judgments in 2014, having found a violation in 74 of them (ECtHR Repot, Romania, 2015). Moreover, even though the EU is under a primary EU law obligation (art. 6(2) TEU) to accede to the ECHR, the Court of Justice of the 
European Union decided in December 2014 that the accession agreement of the EU to the ECHR was not compatible with EU law (CJEU Opinion 2/13). This negative opinion might weaken the EU's future negotiating position, when it comes to including regional human rights agreements in the essential elements clauses of future trade or association agreements.

Turning now to the third instrument, all three Eastern Partners are participating states in the Organization for Security and Co-operation in Europe (OSCE, 2015). Therefore, it is not a surprise that all three essential elements clauses also include The Helsinki Final Act of 1975. However, unlike the ECHR, the Helsinki Final Act is not a binding international document, but a declaration on the principles guiding relations between the participating states. The Final Act includes principles on sovereign equality, inviolability of frontiers, territorial integrity, peaceful settlement of disputes, non-intervention into internal affairs, refraining from the threat or use of force and respect for human rights. Interestingly, Article VII of the Final Act states that the participants "will promote and encourage" the effective exercise of civil, political, economic, social and cultural rights. Therefore, this Act envisages the obligation to 'promote' and 'fulfil' human rights and not just to 'respect' them. Still, as mentioned, it is not a legally binding document. Moreover, the successor (Russia) of one of the original participants (the USSR), which is also a current participant in the OSCE, has acted in contravention of the Final Act's provisions on territorial integrity and the inviolability of frontiers.

The final instrument referred to is the Charter of Paris for a New Europe of 1990 adopted also within the OSCE framework, with the former USSR (of which all three Eastern Partners were members) as a participant. This document is also not binding; however, it offers an explanation of what might be meant by the 'democratic principles' mentioned in all three essential elements clauses. According to the Charter's section on 'Human Rights, Democracy and Rule of Law', "[d]emocracy has as its foundation respect for the human person and the rule of law". Furthermore, free and fair elections are the basis of a democratic government. Therefore, even though rule of law, and free and fair elections are not specifically mentioned in the essential elements clauses, it could be argued that these 'common values' are covered by the term 'democratic principles', the respect of which the contracting parties must ensure.

In light of the above several observations are warranted. First, the reference to these specific regional binding and non-binding human rights and democratic instruments seems warranted due to the political and historical specificities of the three Eastern Partners. All three countries were part of the former USSR and have witnessed communist dictatorship. Furthermore, as evidenced by the number of ECtHR cases, some of them are still struggling with the respect of basic human rights. The inclusion of democratic principles in the essential elements clauses also seemed necessary given the transitional democracy in the partner countries. Second, compared to agreements with partners from Latin America and Korea, 
which only make reference to the UDHR, the three AAs broaden the scope of the essential elements clause to rights and principles, which are not address in the UDHR (Hachez, 2015, p. 16). Third, another explanation for the inclusion of these various regional instruments might have to do with the broader scope of the AAs, which are not simple trade agreements, but envisage close political cooperation as well (Hachez, 2015, p. 17). Fourth, as mentioned, association agreements are also a way for the EU to export its acquis (Matta, 2014) and part of the broader acquis is also the EU's understanding of human rights. This is a means of ensuring that the associate countries also adhere to the EU's understanding of the universality of human rights (Leino, 2005, p. 11).

\section{MONITORING, IMPLEMENTATION AND ENFORCEMENT}

In order to properly understand the 'non-execution' clause, one has to first look at the institutional framework set-up by the AAs. Each agreement sets up its own institutions, which are charged with the implementation of the agreement. In the event of a violation of an essential element recourse should first be had to the bilateral bodies and only if that fails should parties take unilateral measures (Bartels, 2005, pp. 129-130). Therefore, this Chapter will first look at the bodies set up by the AAs tasked with the monitoring and implementation of the agreement, as well as the general dispute settlement provisions. Following this, the setup and the application of the 'non-execution' clause is discussed.

\section{Bodies Tasked with Monitoring and Implementation}

One of the main criticisms of the implementation and enforcement of human rights clauses is the lack of permanent human rights committees under the agreements, whose mandate would be to discuss human rights concerns and monitor the implementation of human rights by the parties (European Parliament, 2014, p. 17). All of the three AAs set up an almost identical institutional framework. Each agreement provides for the creation of an Association Council which shall supervise and monitor the application and implementation of the agreements, as well as examine "any major issues arising within the framework" of the agreements (Arts. 434(1)-(3), EU-Moldova AA; Arts. 404(1)-(2), EU-Georgia AA; Arts. 461(1)-(3), EU-Ukraine AA). The Association Council consists of members of the Council of the EU and the European Commission, on the one hand, and members of the Government of the associate country, on the other (Art. 435(1), EU-Moldova AA; Art. 405(1), EU-Georgia AA; Art. 462(1), EU-Ukraine AA). Moreover, it can adopt decisions which are binding on the contracting parties (Art. 436(1), EU-Moldova AA; Art. 406(1), EU-Georgia AA; Art. 463(1), EU-Ukraine AA). The first meeting of the EU-Moldova Association Council was held on 16 March 2015 (Council of the EU, 2014). 
The Association Council is helped in the performance of its duties by an Association Committee, which can adopt binding decisions if the Association Council has delegated it the power to do so. In all three cases the Association Committee shall meet in a special configuration to address issues related to trade and trade-related matters (Arts. 437-8, EU-Moldova AA; Arts. 407-8, EU-Georgia AA; Arts. 464-5, EU-Ukraine AA). The Association Committee is then assisted by sub-committees. The Association Council can set up special committees or bodies and the Association Committee can also create sub-committees (Art. 439, EU-Moldova AA; Art. 409, EU-Georgia AA; Art. 466, EU-Ukraine AA).

Each agreement also sets up a Parliamentary Association Committee, with members from the European Parliament and the legislatures of the Eastern Partners. This Committee can request relevant information regarding the implementation of the agreements from the Association Council and can make recommendations (Arts. 440-1, EU-Moldova AA; Arts. 410-11, EU-Georgia AA; Arts. 467-68, EU-Ukraine AA). However, it cannot adopt binding decisions. The last possibility for dialogue between the parties is the Civil Society Platform, which consists of members of the European Economic and Social Committee (EESC) and representatives of civil society from the associate countries. The Platform can make recommendations to the Association Council and the Association Committee. Furthermore, the Parliamentary Association Committee shall organise regular meetings with the representative of the Platform (Arts. 442-3, EU-Moldova AA; Arts. 412-13, EU-Georgia AA; Arts. 469-70, EU-Ukraine AA).

Some aspects of this institutional set-up are laudable. First, the democratic input into the decision-making of the Association Council is increased, by allowing the Parliamentary Association Committee to make recommendations. Second, the input of civil society is also increased by allowing members of the civil society from the associate country to regularly meet with the members of the EESC and by allowing the Civil Society Platform to propose recommendations to the Association Council. Third, dialogue and exchange of information is emphasised; both the Parliamentary Association Committee and the Civil Society Platform can request information from the Association Council and shall be informed of decisions taken and recommendations taken by the Association Council. Moreover, there is regular dialogue between the different committees and platforms.

However, some criticism is still warranted. First, it is quite obvious that trade and trade-related matters occupy the central theme in the agreements. In Section II we have seen that special dispute settlement mechanisms are set up for trade related matters. In this Section we can see that the Association Committee shall sit in a special format only when issues regarding trade are concerned. Therefore, even if human rights constitute an essential element to these agreements, from the perspectives of the institutional framework and the dispute settlement mechanism it is fairly evident that trade and trade-related matters are the focus of 
the AAs. Second, even though the democratic input and the input of civil society is increased, these committees and platforms can only make recommendations and not binding decisions. The final binding decisions are in the end still in the hands of the Association Council, representing the 'government/executive-type' power. Third, while different sub-committees can be set up by the Association Council or the Committee, no permanent sub-committee exists which is tasked with the monitoring and supervision of the implementation of the human rights clauses. This seems to support one of the main criticisms voiced by Aaronson (2011), according to whom the EU does not have mechanisms under such agreements to examine the broad impact of its trade policies on human rights, but instead hires independent consultants to do so (p. 441).

\section{The General Dispute Settlement Mechanisms}

Now that we are familiarised with the institutional structure of the AAs and before looking at the actual 'non-execution' clauses of the three AAs it is also important to know where the clauses fit into the overall dispute settlement mechanism set up by the agreements.

As discussed in Section II, Article 421 of the EU-Georgia AA, Article 454 of the EU-Moldova AA and Article 477 of the EU-Ukraine AA provide for the general disputesettlement clauses of the agreements and precede the 'non-execution' clauses; therefore it is important to understand them. Under these articles, when a dispute arises between the contracting parties over the "interpretation, implementation, or good faith application" of the agreements, any party shall submit to the other one and the Association Council a formal request to resolve the dispute. The parties shall then "endeavour" to resolve the dispute by entering into good faith consultations within the Association Council and other relevant bodies, with the objective to reach a "mutually acceptable" solution. The parties shall also provide the Association Council with all relevant information and the dispute is resolved when the Association Council delivers a binding decision or if the dispute has ended.

It is evident that the emphasis falls on mutual dialogue and cooperation in order to achieve a solution which is acceptable to both parties. However, this general rule has an exception to it. Under the first paragraphs of the afore-mentioned articles, disputes relating to trade and trade-related matters are exclusively governed by the dispute settlement chapters under the Titles on "Trade and Trade-Related Matters". The trade related dispute settlement mechanism is modelled upon the WTO Dispute Settlement Understanding and it is included in most of the recent FTAs concluded by the EU (Van der Loo et al., 2014, p.20). This once again illustrates that beyond human rights conditionality and the importance attached to it, the actual main objective of all three AAs is to create a Deep and Comprehensive Trade Area with the EU. This of course raises the question whether human rights clauses are not mere political clauses. Unlike trade related matters, human rights do not benefit from a specially 
created committee, nor do they benefit from special dispute settlement procedures. Moreover, practice shows us that even the clauses meant to protect them are triggered very rarely.

\section{The Operation of the 'Non-Execution' Clause}

The 'non-execution' clause does not exist as a self-standing island within the agreement. Instead it is intertwined with the institutional and dispute-settlement fabric of the agreement. Furthermore, the practical operation of the 'non-execution' clause is not without criticism. Let us first look at these criticisms and then turn to the specific 'non-execution' clauses within the three AAs.

\section{a. The Historical and Practical Perspective}

As discussed in Section II, the standard 'non-execution' clause is the Bulgarian type clause, allowing the parties more flexibility to adopt 'appropriate measures'. 'Non-execution' clauses regularly establish a two-track procedure for taking appropriate measures. For 'normal' cases the matter is resolved within the bodies set up under the agreement, while in cases of 'serious urgency' the party may act unilaterally (Bartels, 2005, p. 132). In practice, when unilateral action is sought by the EU, the Commission proposes appropriate measures to the Council, which shall enforce the human rights conditionality clauses through a Council Decision (European Parliament, 2014, p. 17). This practice is based on the assumption that the adoption of 'appropriate measures' constitute suspension of the agreement under Article 218(9) TFEU (Bartels, 2014). Under this paragraph it is the Council that decides on the suspension of an international agreement, following a proposal from the Commission or the High Representative. The Parliament is only informed of these proceedings (Article 218(10) TFEU).

However, the practical operation of the 'non-execution' clause is not without its criticism, which Hachez sums up excellently. The first criticism is that even though the EU goes to great lengths to include human rights conditionality into its international agreements the EU seldom activates conditionality and regularly leaves human rights violations by its partner countries unpunished (Hachez, 2015, p. 17). A second critique is that the EU triggers the 'non-execution' clause selectively, doing so against 'harmless' partners (such as AfricanCaribbean-Pacific states) but failing to do so against more powerful countries. A third critique concerns the usage of the human rights conditionality clauses only in very grave and sudden situations, such as government coups, flawed elections or grave human rights violations. Moreover, in most cases the activation of conditionality clauses leads to dialogues and consultations, but very rarely to the suspension of the agreement (Hachez, 2015, pp. 17-18). 


\section{b. The Specific 'Non-Execution' Clauses: 'Nothing New Under the Sun'}

Article 422 of the EU-Georgia AA, Article 455 of the EU-Moldova AA and Article 478 of the EU-Ukraine AA provide for almost identical clauses on "appropriate measures in case of non-fulfilment of obligations". These clauses do not differ from other 'non-execution' clauses when it comes to their two-tier structure. They provide for 'normal' situations when appropriate measures can be sought. Thus, a contracting party can take appropriate measures if an issue is not resolved within three months from when a formal request to dispute settlement was notified and if the complaining party continues to consider that the other party has failed to fulfil an obligation under the agreement. When selecting appropriate measures, priority shall be given to those "which least disturb" the functioning of the agreement. Such measures cannot include suspension of rights or obligations under the trade-related Titles and they must be notified immediately to the Association Council where it will be subject to consultations and the general dispute settlement mechanism (Art. 455(2), EU-Moldova AA; Art. 422(2), EU-Georgia AA; Art. 478(2), EU-Ukraine AA).

However, two exceptions are mentioned to these rules: (a) denunciation of the agreements not sanctioned by general rules of international law, or (b) violations by the other contracting party of any of the 'essential elements' of the agreements. Thus, whenever an essential element is violated by one of the parties, the other party does not follow the regular dispute settlement mechanism and can take 'appropriate measures'. In other words, unilateral action is possible when an essential element is violated without involving the Association Council.

Some observations are necessary. It seems that these exceptions follow the logic of Article 60 VCLT 1969, under which a material breach of a bilateral treaty by one of the parties entitles the other to invoke the breach as a ground of terminating or suspending (in whole or in part) the agreement. For the purposes of this article "(a) [a] repudiation of the treaty not sanctioned by the present Convention; or (b) [t]he violation of a provision essential to the accomplishment of the object or purpose of the treaty" shall constitute a material breach of treaty. Therefore, it seems that the breach of an essential element in the AAs is considered to be a violation, under international law, of a provision which is 'essential' to the accomplishment of the purpose of the AA and warrants its suspension.

However, in practice 'appropriate measures' are rarely applied and often only entail the suspension of meetings and technical co-operation programs (Hachez, 2015, p. 19). Only in very rare cases does the Council suspend the agreement or parts of it, such as in the case of the more recent suspension of the EEC-Syria Cooperation Agreement due to the systematic violations of human rights by Syria (Council Decision 2011/523/EU). Moreover, as Hachez notes, in general conditionality lacks a proper 'operational mechanism' for the 
implementation and monitoring of human rights, as well as the evaluation of effectiveness of sanctions. Furthermore, the 'non-execution' clauses of the three AAs do not lay down what exactly would constitute a 'violation' of the essential elements. As mentioned, past practice has shown that only very grave breaches are taken into consideration by the EU, such as government coups or gross violations of human rights.

\section{CHALLENGES AND SOLUTIONS}

\section{Various Challenges Voiced in Legal Academia and Proposed Solutions}

Over the years different authors have voiced various concerns over the functioning of human rights conditionality in EU agreements, with some of them also proposing various solutions to combat these shortcomings. Aaronson (2011) has voiced her critiques in a general manner, regarding human rights conditionality in agreements concluded by the EU, USA, Canada, etc. One such critique is that we do not yet know whether disincentives, such as sanctions, result in better human rights protection in the host country, than for example various incentives. Moreover, the links between trade and human rights are not yet fully discussed in academia and more empirical and qualitative studies are needed to assess the costs and benefits of human rights conditionality (pp. 446-447). A decade ago, Leino (2005) has criticized the EU's lack of consistency in applying human rights conditionality to agreements concluded with developing states, but not doing so with developed states (p. 359). However, we have seen that the recent Framework Agreement with South Korea, a developed nation, includes human rights conditionality.

Hachez's (2015) main criticism deals with the monitoring and enforcement phase of the human rights clauses. According to him no agreement has thus far established a specific organ charged with the monitoring of human rights and no proper 'operational mechanism' is set up overseeing the implementation of human rights and the evaluation of the effectiveness of sanctions (pp. 19-20). Furthermore, contrary to other FTAs such as the North Atlantic Free Trade Agreement (NAFTA), EU agreements do not contain any standard procedure under which a right of individual petitions is recognised in order to investigate alleged human rights violations in a partner country (Hachez, 2015, pp. 19-20). These concerns also appear in the recent studies of Bartels conducted for the European Parliament and the German Institute for Human Rights. He also adds that there is no mechanism yet to deal with the situation when the partner country might want to suspend the agreement in order not to infringe its own human rights obligations (European Parliament 2014, pp. 19-20; Bartels, 2014, p. 28).

In order to remedy such concerns, Bartels in its study for the European Parliament (2014) has proposed several solutions some of which are pertinent for the purposes of this Chapter. First, he proposes that essential elements clauses should contain references to 'all 
other relevant international agreements' and in certain cases it might be appropriate to set a specific benchmark for human rights obligations, the failure of which would trigger 'appropriate measures' (European Parliament, p. 23). Second, agreements should contain human rights exceptions permitting either party to suspend its trade obligations when necessary to comply with its own human rights obligations (p. 24). Third, a permanent human rights committee should be set up tasked with the monitoring of compliance of the parties with their human rights obligations under the agreement. This should be coupled with a mechanism for periodic human rights impact assessments (p. 24). Fourth, civil society should be allowed to "bring complaints to the parties to initiate an investigation by the European Commission into human rights issues arising under the agreement" (Bartels, 2014, p. 9). In light of these recommendations, let us shortly look at whether the three newly concluded AAs contain some of these improvements.

\section{Do the New AAs Provide Solutions for Existing Challenges?}

In the upcoming sections let us look at how some of these existing challenges have been dealt with in the newly concluded AAs.

\section{a. A Reference to "All Other Relevant" International Human Rights Agreements}

According to Bartel's first recommendation, all essential elements clauses should have a reference to all other relevant international agreements on human rights. Furthermore, a benchmark should be set up within the agreement to measure a breach of human rights or democratic principles. Failing to reach this benchmark would trigger appropriate measures. Compared to other recent trade agreements, such as the FTA with Colombia and Peru which only refers to respect of human rights as laid down in the UDHR (Article 1), the three AAs refer to the UDHR and several regional human rights instruments (supra Section III) since all three Eastern Partners are members of regional bodies, such as the Council of Europe and the OSCE. However, only the agreement with Ukraine refers to 'other relevant human rights instruments'. As discussed in Section III, this gives certain flexibility to the EU-Ukraine AA to include future human rights instruments as well.

With regard to the benchmark for violations of essential elements, none of the three agreements set out such benchmarks. Even so, it is arguable whether the existence of such a benchmark would not in fact cause more confusion in the application of human rights clauses. It seems very difficult to create such a benchmark, since it would need to contain clauses dealing with the gravity of the breach, its systemic character and the burden of proof. First, regarding the gravity of the breach, one would have to choose between a qualitative and/or a quantitative assessment on a case-by-case basis. For e.g., one could argue that 
repeated cases in which the ECtHR has held that one of the partner countries has breached a fundamental right, such as the right to property, is as important/or not as important as having one ECtHR case in which it was found that core human rights, such as the right to life or the prohibition of torture have been breached. Second, the time period is also important to know whether such violations of essential elements have occurred only once or systematically over a period of time. It might be argued that in case of human rights, systematic and grave violations could trigger the 'appropriate measures', while in the case of the breach of democratic principles a one-time government coup would suffice. Third, there is also the problem of the burden of proof and evidence. What evidence would be allowed and who would need to prove the systematic and grave breach?

\section{b. The Partner Country's Risk of Breaching its own Human Rights Obligations}

Under the second recommendation a party should be allowed to suspend the trade related parts of the agreement if applying them would risk breaching the partner's own human rights obligations. However, none of the three agreements contain such clauses. Most suspensions related to the trade parts of the agreements concern either the suspension of particular benefits in case the partner country did not approximate its legislation with the EU acquis (Art. 410(7), EU-Moldova AA; Art. 274(6), EU-Georgia AA) or the temporary suspension of the Agreement or the trade-related parts if the full implementation and enforcement of the AA is not ensured in the partner country (Art. 462(4), EU-Moldova AA; Art. 429(4), EU-Georgia AA).

\section{c. A Permanent Human Rights Committee}

The third recommendation refers to the setting up of a permanent human rights committee charged with monitoring and overseeing the implementation of the human rights clauses. In Section IV we have discussed the identical institutional frameworks set up by the three AAs. Even though the Association Council and the Association Committee can create extra sub-committees, no permanent human rights committee is set up, and the only special configuration refers to trade and trade-related matters. Therefore, the institutional structure does not yet meet the recommendations put forward by Bartels. However, at least some progress has been made, by the creation of the Parliamentary Association Committees, which even though cannot make binding decisions, they can make recommendations to the Association Councils, they must be informed of all the decisions taken by the Association Council and they can request information from the Association Councils concerning the implementation of the agreements (Art. 441, EU-Moldova AA; Art. 411, EU-Georgia AA; Art. 468, EU-Ukraine AA). 
Furthermore, it can be argued that the establishment of a permanent human rights committee is not always necessary, since a lot of structures and instruments exist or have been recently set-up which are tasked with the monitoring and implementation of human rights in the partner countries. On an EU level the High Representative has recently issued a joint communication on the review of the ENP in which she proposes a stronger neighbourhood, taking into consideration the individual interests and concerns of the partner countries, and focusing on fewer priorities. However, essential elements still remain a high priority, since the ENP will seek more effective ways to promote good governance, democracy, the rule of law and human rights (EEAS, Joint Communication, 2015, p. 4). The effectiveness of existing instruments to further the rule of law and human rights protection has been recently criticized by practitioners and academics (Hague Institute for Global Justice, 2015). Therefore, it is not a surprise that the recent joint communication introduces a new mechanism through which progress reports on the ENP will not be done simultaneously, but will be country specific (EEAS, Joint Communication, 2015, p. 5). These reports will contain the elements required under the Regulation on the European Neighbourhood Instrument (ENI). One of the objectives of the ENI Regulation is to promote human rights and fundamental freedoms, good governance, democracy and the rule of law (Art. 2(2)a, Reg. 232/2014). The achievement of such objectives will be measured in the relevant EU periodic reports using the indicators established by international organizations and relevant bodies (Art. 2(3), Reg. 232/2014).

With regard to the implementation of human rights protection, the Commission already has programmes in place meant to help the Eastern Partners achieve the goals in the essential elements clauses. For example, in 2014 the Commission set up a Support Group for Ukraine to support the Ukrainian authorities in achieving the goals of the 'European Agenda for Reform' (European Commission, International Cooperation and Development/Ukraine, 2015). The Agenda includes among others, continued efforts to improve the electoral and legislative framework as well as improving the rule of law and the respect for human rights (European Commission, EU-Ukraine. A European Agenda for Reform, 2015). Furthermore, the situation in Ukraine has also been on the agenda of the Human Rights Council in July 2015 (EEAS, Human Rights Council, 2015). The Council has also adopted a new Action Plan on human rights and democracy, which among others is meant to "[i]ncrease coherence and complementarity of existing EU tools, financing instruments and reporting mechanisms used to promote human rights and support democracy," including the afore-mentioned ENP progress reports (Council of the EU Action Plan, 2015, point 33).

Looking at regional organizations, the Council of Europe is also engaged in various projects, such as the Promotion of Human Rights Education and Democratic Citizenship in Eastern Partner countries (Council of Europe, 2015). The OECD is also involved in various projects, such as the Ukraine anti-corruption project (OECD, Ukraine, 2015), while the 
OSCE has created an assessment report on the performance evaluation of judges in Moldova (OSCE, Moldova, 2015).

On the international level, the Office of the United Nations High Commissioner for Human Rights (OHCHR) has periodic, multi-annual reports on Ukraine. For example, the OHCHR Report on the human rights situation in Ukraine from 16 February to 15 May 2015 looked at the protection and breach of core human rights (rights to life, liberty, security and physical integrity), fundamental freedoms, economic and social rights and the accountability and administration of justice by the Ukrainian Government and the rebel forces in the Donbas area (OHCHR, Ukraine, 2015). The OHCHR also draws-up regular reports on human rights protection in Moldova (OHCHR, Moldova, 2015) and Georgia (OHCHR, Georgia, 2015). Such reports can become useful also to the bodies set up under the AAs to check for systematic and grave human rights violations.

In conclusion, even though the creation of a permanent human rights committee would have been an optimal solution, the monitoring and implementation of human rights, the rule of law and democratic principles in the partner countries is achieved in different ways on multiple levels.

\section{d. Enhanced Involvement of Civil Society}

According to the fourth recommendation, similarly to some US FTAs, individual petitions should be allowed before the Commission in order to launch investigations for alleged breaches of human rights. While such a right of petition is not yet provided in the three AAs, some progress has been made with the creation of Civil Society Platforms. As explained, these Platforms also include members of the Eastern Partner's civil society. Furthermore, they can make recommendations to the Association Council, they must be informed of all decisions taken by the latter and they shall take part in regular meetings with the Association Committees and the Parliamentary Association Committees (Arts. 440-1, EU-Moldova AA; Arts. 410-1, EU-Georgia AA; Arts. 467-8, EU-Ukraine AA). Therefore, even though a direct possibility of a petition to the Commission does not yet exist, members of the partner country's civil society do have a role to play in the institutional set-up and decision-making under these agreements.

Furthermore, according to the High Representative's recent Joint Communication the EU will look to support citizen's ability to hold governments accountable and shall further support sub-national, national and intra-regional civil society. The EU should also support developing the capacities of civil society professionals, using programmes such as the Civil Society fellowships (EEAC, Joint Communication, 2015, p. 6). Projects also exist on the national level for the countries from the Western Balkans, a model which could be used for the Eastern Partners as well. For example, under the MATRA project, the Netherlands 
regularly develops training programmes for civil servants, judges and legal professionals from the Western Balkans (Matra Project, 2015). Another area where civil society should be encouraged is the enactment of policies that are meant to improve the rule of law, democracy and the protection of human rights.

\section{CONCLUSION}

The Association Agreements with Ukraine, Moldova and Georgia provide a new template for future agreements the EU will conclude or is about to conclude with its remaining partners in the European Neighbourhood Policy. Human rights conditionality is present in all three agreements; the 'essential elements' clauses are more detailed than in previous agreements, referring to relevant international and regional human rights instruments, democratic principles and other elements which are essential in the specific context. These clauses are coupled with Bulgarian type 'non-execution' clauses under which the parties can opt for 'appropriate measures' if one of the parties breaches one of the essential elements. The institutional structure is also more robust than in previous agreements, and the Parliamentary Committees and Civil Society Platforms bring added value to the agreements.

However, the agreements did not address all concerns raised by academics and practitioners. First, no rules are included concerning the benchmark that would trigger a violation of the essential elements, leaving the application of human rights conditionality to be dealt with on a case-by-case basis. Still, the creation of such a benchmark would be difficult to construct and would need to take into consideration multiple factors. Second, while the institutional structure is robust, a permanent human rights committee charged with the monitoring and implementation of human rights under the agreements would have been welcomed. Even so, there are many recent national, regional, EU level and international instruments through which the monitoring and implementation of essential elements in the Eastern Partners is strengthened.

One of course cannot deny the fact that all three agreements are predominantly concerned with trade and trade-related aspects. These parts are the most extensive ones in all three AAs and include special dispute settlement procedures. These are all signs that human rights conditionality in the new generation of AAs with the Eastern Partners still represents rather political commitments and political conditionality, while the actual trade related matters form the core objectives of these agreements. 


\section{List of References}

\section{Books and Chapters in Edited Books}

Aaronson, S.A (2011). Human Rights. In J-P. Chauffour \& J-C. Maur (Eds.), Preferential Trade Agreements. Policies for Development (429-452). World Bank Publications.

Bartels, L., (2005). Human Rights Conditionality in the EU's International Agreements. Oxford: Oxford University Press.

Ghazaryan, N., and Hakobyan, A. (2014). Legislative Approximation and Application of EU Law in Armenia (191-214). Ghazaryan, N. (2014). Legislative Approximation and Application of EU Law in Azerbaijan (215-227). Karliuk, M. (2014) Legislative Approximation and Application of EU Law in Belarus (228-245). In P. Van Elsuwege \& R. Petrov (Eds.), Legislative Approximation and Application of EU Law in the Eastern Neighbourhood of the European Union. Towards a Common Regulatory Space? Routledge.

Hillion, Ch. (2014). Anatomy of EU Norm Export Towards the Neighbourhood. In P. Van Elsuwege \& R. Petrov (Eds.), Legislative Approximation and Application of EU Law in the Eastern Neighbourhood of the European Union. Towards a Common Regulatory Space? (pp. 13-20). Routledge.

Kalinichenko, P. (2014). Legislative Approximation and Application of EU Law in Russia. In P. Van Elsuwege \& R. Petrov (Eds.), Legislative Approximation and Application of EU Law in the Eastern Neighbourhood of the European Union. Towards a Common Regulatory Space? (pp. 246-260). Routledge.

Kochenov, D. (2014). The Issue of Values. In P. Van Elsuwege \& R. Petrov (Eds.), Legislative Approximation and Application of EU Law in the Eastern Neighbourhood of the European Union. Towards a Common Regulatory Space? (pp. 46-62). Routledge.

Matta, A. (2014). Differentiating the Methods of Acquis Export: The Case of the Eastern Partners and Russia. In P. Van Elsuwege \& R. Petrov (Eds.), Legislative Approximation and Application of EU Law in the Eastern Neighbourhood of the European Union. Towards a Common Regulatory Space? (pp. 21-45). Routledge.

\section{Journals, Periodicals and Working Papers}

Hachez, N., (2015). "Essential Elements" Clauses in EU Trade Agreements Making Trade Work in a Way that Helps Human Rights? Leuven Centre for Global Governance Studies, Working Paper No. 158.

Horn, H., Mavroidis, P. C. \& Sapir, S. (2010). Beyond the WTO? An Anatomy of EU and US Preferential Trade Agreements. The World Economy 33, 1565-1588.

Kawecka-Wyrzykowska, E. (2015). The EU-Georgia Association Agreement: An Instrument to Support the Development of Georgia or Lip Service? Comparative Economic Research 18, 77-97.

Leino, P. (2005). European Universalism? - The EU and Human Rights Conditionality. Yearbook of European Law 24, 329-383.

Movchan, V., \& Shportyuk, V. (2012). EU-Ukraine DCFTA: The Model for Eastern Partnership Regional Trade Cooperation. CASE Network Studies and Analyses No. 445/2012. 
Petersmann, E-U. (2015). Transformative Transatlantic Free Trade Agreements without Rights and Remedies of Citizens. Journal of International Economic Law 18, pp. 579-607.

Van der Loo, G., Van Elsuwege, P., \& Petrov, R. (2014). The EU-Ukraine Association Agreement: Assessment of an Innovative Legal Instrument. EUI Working Paper Law 2014/09, 1.

\section{Treaties and Legislation}

Association Agreement between the European Union and the European Atomic Energy Community and their Member States, of the one part, and the Republic of Moldova, of the other part (2014).

Association Agreement between the European Union and the European Atomic Energy Community and their Member States, of the one part, and Georgia, of the other part (2014).

Association Agreement between the European Union and its Member States, of the one part, and Ukraine, of the other part (2014).

Council Decision 2011/523/EU, partially suspending the application of the Cooperation Agreement between the European Economic Community and the Syrian Arab Republic.

Council Regulation 442/2011 concerning restrictive measures in view of the situation in Syria repealed by Council Regulation 36/2012.

Framework Agreement between the European Union and Its Member States, of the one part, and The Republic of Korea, of the other part (2010).

Trade Agreement between the European Union and Colombia and Peru (2012).

Treaty on the European Union (2007).

Treaty on the Functioning of the European Union (2007).

Vienna Convention on the Law of Treaties (1969).

\section{Court Cases and Opinions}

Stjerna v Finland [1997] 24 EHRR 195

Von Hannover v Germany [2005] 40 EHRR 1

$X$ and $Y$ V Netherlands [1986] 8 EHRR 235

CJEU Opinion 2/13, Accession of the EU to the ECHR, ECLI:2014:2454

\section{Reports, Studies, Communications and Online Sources}

Bartels, L., (2014). A Model Human Rights Clause for the EU's International Trade Agreements. Study for the German Institute of Human Rights and Misereor.

Council of Europe (2015). Council of Europe Projects in Ukraine. Retrieved on 22 November 2015, from http://www.coe.int/en/web/kyiv/field-office-information/projects-programmes. 
Council of the EU (2015). Joint Press Release Following the First Association Council Meeting Before the European Union and the Republic of Moldova. Retrieved on 22 November 2015, from http://www.consilium.europa.eu/en/press/press-releases/2015/03/16-first-association-council-meetingbetween-european-union-republic-moldova/.

Council of the EU (2015). Action Plan on Human Rights and Democracy 2015-2019. Retrieved on 22 November 2015, from http://data.consilium.europa.eu/doc/document/ST-10897-2015-INIT/en/pdf.

European Commission, Communication (2001). The European Union's Role in Promoting Human Rights and Democratisation in Third Countries. COM(2001) 252.

European Commission, Joint Communication to the European Parliament and the Council (2011). Human Rights and Democracy at the Heart of EU External Action - Towards a More Effective Approach. $\operatorname{COM}(2011) 886$.

European Commission (2014). EU-Ukraine. A European Agenda for Reform. Retrieved on 22 November 2015, from http://ec.europa.eu/archives/commission_2010-2014/fule/docs/ukraine/a_european_agenda_for reform.pdf.

European Commission, DG Trade (2015). Russia. Retrieved on 22 November 2015, from http://ec.europa.eu /trade/policy/countries-and-regions/countries/russia/.

European Commission (2015). International Cooperation and Development.Ukraine. Retrieved on 22 November 2015, from https://ec.europa.eu/ europeaid/countries/ukraine_en.

European Court of Human Rights (2015). Press Country Profile Republic of Georgia. Retrieved on 22 November 2015, from http://www.echr.coe.int/Documents/CP_Georgia_ENG.pdf

European Court of Human Rights (2015). Press Country Profile Republic of Moldova. Retrieved on 22 November 2015, from http://www.echr.coe.int/Documents/CP_Republic_of_Moldova_ENG.pdf

European Court of Human Rights (2015). Press Country Profile Republic of Romania. Retrieved on 22 November 2015, from http://www.echr.coe.int/Documents/CP_Romania_ENG.pdf.

European Court of Human Rights (2015). Press Country Profile Republic of Ukraine. Retrieved on 22 November 2015, from http://www.echr.coe.int/Documents/CP_Ukraine_ENG.pdf

European External Action Service (2015). EU Relations with Eastern Partnership. Retrieved 22 November 2015, from http://eeas.europa.eu/eastern/index_en.htm.

European External Action Service (2015). EU Relations with Armenia. Retrieved on 22 November 2015, from http://eeas.europa.eu/armenia/index_en.htm.

European External Action Service (2015). EU Relations with Azerbaijan. Retrieved on 22 November 2015, from http://eeas.europa.eu/azerbaijan/index_en.htm.

European External Action Service (2015). EU Relations with Belarus. Retrieved on 22 November 2015, from http://eeas.europa.eu/belarus/index en.htm.

European External Action Service, Joint Communication (2015). Review of the European Neighbourhood Policy. Retrieved on 22 November 2015, from http://eeas.europa.eu/enp/documents/2015/151118 jointcommunication_review-of-the-enp_en.pdf. 
European External Action Service (2015). Outcomes of the 29th session of the Human Rights Council from a European Union perspective (03/07/2015). Retrieved on 22 November 2015, from http://eeas.europa.eu/delegations/un_geneva/press_corner/all_news/news/2015/20150703_hrc29_outcomes_e n.htm.

European Parliament, Policy Department DG External Policies(L. Bartels)(2014).The European Parliament's Role in Relation to Human Rights in Trade and Investment Agreements. EXPO/B/DROI.2012-09.

Government of the Netherlands (2015). Matra Social Transfromation Programme. Retrieved on 22 November 2015, from https:/www.government.nl/topics/matra/contents/grant-for-strengthening-democracy-matra-ruleof-law.

OECD (2015). Ukraine Anti-corruption Project. Retrieved on 22 November 2015, from http://www.oecd.org/countries/ukraine/ukraine-oecd-anti-corruption-project.htm.

OHCHR (2015). Georgia. Retrieved on 22 November, from http://www.ohchr.org/EN/ countries/ENACARegion/Pages/GEIndex.aspx.

OHCHR (2015). Report on the human rights situation in Ukraine 16 February to 15 May 2015. Retrieved on 22 November 2015, from http://www.ohchr.org/Documents/Countries/UA/10thOHCHRreportUkraine.pdf.

OHCHR (2015). Republic of Moldova. Retrieved on 22 November 2015, from http://www.ohchr.org/EN/countries/ENACARegion/Pages/MDIndex.aspx.

OSCE (2015). Participating States. Retrieved on 22 November 2015, from http://www.osce.org/states.

OSCE (2015). Report and Legal Opinion on Performance Evaluation of Judges in Moldova. Retrieved on 22 November 2015, from http://www.osce.org/odihr/120342.

Peers, S. (2014). The CJEU and the EU's accession to the ECHR: a clear and present danger to human rights protection. Retrieved on 22 November 2015, from http://eulawanalysis.blogspot.nl/2014/12/the-cjeu-and-eusaccession-to-echr.html.

The Hague Institute for Global Justice (2015). Public Trust in Judicial Institutions in the Eastern Partnership Countries. Retrieved on 22 November 2015, from http://www.thehagueinstituteforglobaljustice. org/events/public-trust-in-judicial-institutions-in-the-eastern-partnership-countries/\#content. 